\title{
The nature of the Old World savannah palaeobiome
}

\begin{abstract}
To the Editor - Writing in Nature Ecology \& Evolution in 2018, we argued that there existed during the later Miocene of the Old World (ca. 15-5 million years ago) "a single cohesive Old-World savannah palaeobiome of which the modern African savannah fauna is the surviving branch"1. Subsequently, Denk et al. ${ }^{2}$ have taken issue with this interpretation and argued, using palaeobotanical data, that no such cohesive biome existed and that a more compelling reconstruction has mixed trees and shrublands dominant at that time. In addition to defending our original interpretation, we will clarify some terms used in our paper, as we feel that much of the apparent discrepancy may actually reflect differences in terminology.
\end{abstract}

We used the term savannah in a broad sense, common in Neogene and Quaternary palaeoecology $y^{3}$, meaning a woodland to grassland biome characterized by co-dominance of trees and grasses ${ }^{4}$, the 'mixed grass-tree biome' described in ref. ${ }^{5}$. In contrast, Denk et al., approaching the matter from a botanical perspective, adhere to a more restricted definition of savannah as grasslands. We formulated the term Old World savannah palaeobiome (OWSP) to describe localities showing high similarity to our selected reference localities (Lower Nawata, Pikermi and Baode) characterized by large mammal communities dominated by groups associated with open habitats ${ }^{6,7}$. These localities have all been previously identified as representatives of woodlanddominated or mixed woodland-grassland ecosystems ${ }^{8-11}$ through methods independent of mean ordinated hypsodonty. The evidence includes microwear, mesowear, stable isotope, phytolith, sedimentological and that from functional morphological approaches, and covers Late Miocene sites from Turkey, Hungary, Bulgaria, Greece, Iran and China ${ }^{8-18}$. The critique by Denk et al. of our interpretations therefore stands against an extensive multiproxy literature that repeatedly confirms the dominance of woodland and grassy woodland environments across a wide swath of Eurasia and Africa during the late Miocene.

We used the term cohesive to describe the OWSP, to which Denk et al. object, to imply interconnectedness of the faunal assemblages rather than uniformity of vegetation cover, which we should have made more explicit. The genus-level similarity analysis of large mammal faunas was used to trace the origin and dispersal of mammals within the OWSP as it expanded and contracted in sync with the environment, which we approximated by mean hypsodonty (our Figs. 2 and 3 in ref. ${ }^{1}$ ). It was cohesive in the sense of the connectedness of internal dispersal of fauna, not in the sense of being at all times and in all places a uniform system. We proposed that in the OWSP, the diverse habitat of the Hipparion fauna ${ }^{19}$, increasing overall and seasonal aridity created a world in which herbivores were progressively adapting to similar limiting conditions over vast areas.

It is not unexpected for phytological and zoological proxies to result in differing reconstructions. Even present-day mammal zoogeography (for example, Fig. $3 \mathrm{c}$ in ref. ${ }^{20}$ ) does not exactly match terrestrial vegetation biomes (for example, Fig. 4.3 in ref. ${ }^{21}$ ). Within a zoogeographic region, the terrestrial vegetation biomes may vary from semi-desert to forest. It has also been suggested that vertebrate fossils and macrofossils/palynomorph floras may reflect different environmental conditions and climatic cycles ${ }^{11}$, though space prohibits further discussion here.

In principle, the existence of differential vegetation - including forests - within the large area covered by the OWSP is of course inevitable, and we never doubted it. Indeed, such heterogeneity is also suggested by our own results, for example, our Figs. 2 and 3 (ref. ${ }^{1}$ ). We deliberately used the robust but coarse metric of mean ordinated hypsodonty as a proxy for environmental harshness in general ${ }^{22}$. We did so because we expected that, while the local details would vary, the overall effect would be one of lowered ecosystem productivity, increased seasonality and other factors contributing to harshness. Although more detailed ecometric models of climate or vegetation were available, we accordingly selected mean hypsodonty as the appropriate metric ${ }^{23-27}$.

Denk et al. have presented a welcome basis for the holistic survey of evidence, and we look forward to discovering what exactly the floristic patterns mean in terms of habitats and ecosystems, and whether there is any actual disagreement in the reconstructions or interpretations of either of the methodologies.

\author{
Mikael Fortelius ${ }^{1 \star}$, Faysal Bibi ${ }^{2}$, Hui Tang ${ }^{3}$, \\ Indrè Žliobaitè ${ }^{4}$, Jussi T Eronen ${ }^{5,6}$ \\ and Ferhat Kaya ${ }^{\top}$
}

${ }^{1}$ Department of Geosciences and Geography, University of Helsinki, Helsinki, Finland. ${ }^{2}$ Museum für Naturkunde, Leibniz Institute for Evolution and Biodiversity Science, Berlin, Germany. ${ }^{3}$ Department of Geosciences, University of Oslo, Oslo, Norway. ${ }^{4}$ Department of Computer Science, University of Helsinki, Helsinki, Finland. ${ }^{5}$ Ecosystems and Environment Research Programme, University of Helsinki, Helsinki, Finland. ${ }^{6}$ BIOS Independent Research Unit, Helsinki, Finland. *e-mail: mikael.fortelius@helsinki.fi

Published online: 18 March 2019

https://doi.org/10.1038/s41559-019-0857-7

\section{References}

1. Kaya, F. et al. Nat. Ecol. Evol. 2, 241-246 (2018).

2. Denk, T., Zohner, C. M., Grimm, G. W. \& Renner, S. S. Nat. Ecol. Evol. 2, 1864-1870 (2018).

3. Sankaran, M. et al. Nature 438, 846-849 (2005).

4. Reed, K. et al. in Early Hominin Paleoecology (eds. Sponheimer, M., Lee-Thorp, J.A., Reed, K. \& Ungar, P.) 3-34 (University Press of Colorado, Boulder, CO, USA, 2013).

5. Beerling, D. J. \& Osborn, C. P. Glob. Change Biol. 12, 2023-2031 (2006).

6. Bernor, R. L., Andrews, P. A., Solounias, N. \& van Couvering, J. A. The evolution of 'Pontian' mammal faunas: some zoogeographic, palaeoecological, and chronostratigraphic considerations. in Annales Geologiques Pays Helleniques, 7th International Congress on Mediterranean Neogene, Athens, Vol. 1, 81- 89 (1979).

7. Eronen, J. T. et al. Proc. Natl Acad. Sci. USA 106, 11867-11871 (2009).

8. Passey, B. H. et al. Earth Planet. Sci. Lett. 277, 443-452 (2008).

9. Solounias, N., Rivals, F. \& Semprebon, G. M. Paleobiology 36, 113-136 (2010)

10. Cerling, T. E. et al. in Lothagam: The Dawn of Humanity in Eastern Africa (eds. Leakey, M. G. \& Harris, J. H.) 605-624 (Columbia University Press, New York, 2003).

11. Uno, K. T. et al. Proc. Natl Acad. Sci. USA 108, 6509-6514 (2011).

12. Strömberg, C. A. E. et al. Palaeogeogr. Palaeoclimatol. Palaeoecol. 250, 18-49 (2007)

13. Bernor, R. L. et al. Ann. Zool. Fennici 51, 201-208 (2014).

14. Solounias, N. et al. in Fossil Mammals of Asia: Neogene Biostratigraphy and Chronology (eds. Wang, X., Flynn, L. \& Fortelius, M.) 676-692 (Columbia Univ. Press, New York, 2013).

15. Merceron, G., Zazzo, A., Spassov, N., Geraads, D. \& Kovachev, D. Palaeogeogr. Palaeoclimatol. Palaeoecol. 241, 637-654 (2006).

16. Merceron, G., Schulz, E., Kordos, L. \& Kaiser, T. M. J. Hum. Evol. 53, 331-349 (2007).

17. Kaya, F. et al. J. Vert. Paleontol. 36, e1071710 (2016).

18. Böhme, M. et al. PLoS One 12, e0177347 (2017).

19. Kurtén, B. Commentationes Biologicae Societatis Scientiarum Fennicae 13, 1-82 (1952).

20. Holt, B. G. et al. Science 339, 74-78 (2013).

21. Millennium Ecosystem Assessment. Ecosystems and human well-being: biodiversity synthesis (World Resources Institute, Washington DC, 2005).

22. Fortelius, M. et al. Annu. Rev. Earth Planet. Sci. 42, 579-604 (2014)

23. Liu, L. et al. Proc. Biol. Sci. 279, 2793-2799 (2012).

24. Fortelius, M. et al. Philos. Trans. R. Soc. Lond. B Biol. Sci. 371, 20150232 (2016).

25. Galbrun, E. et al. Palaeontol. Electron. 21.1.3A, 1-31 (2017).

26. Žliobaite, I. et al. Evol. Ecol. Res. 19, 127-147 (2018).

27. Žliobaitè, I. et al. Proc. Natl Acad. Sci. USA 113, 12751-12756 (2016).

Competing interests

The authors declare no competing interests. 